\title{
AKUNTANSI DAN PENGELOLAAN DANA DESA (STUDI KASUS DESA SUNGAI GELAM KECAMATAN SUNGAI GELAM KABUPATEN MUARO JAMBI
}

\author{
Arna Suryani \\ Dosen Fakultas Ekonomi Univ. Batanghari Jambi
}

\section{ABSTRACT}

This research aims to provide insight to the village authorities about the problems that plagued the village related to accounting and financial management of the village Fund. Research conducted in the village of Sungai Gelam Sub River Gelam Muaro Jambi Regency. Types of data used in this research is the primary data and secondary data. The method of data collection is carried out triangulation (combined), namely in the form of observations (observation), interview (interview), the library (library reaserch), and documentation (documentation). This research is descriptive research using qualitative approach with an analysis of inductive or qualitative in nature. This research seeks mendiskripsikan a clear picture of the phenomena that occur in the application of accounting and financial management of the village. The results showed all transactions that originate from the village Fund Allocation has been recorded using a recording system of accountancy assisted by computer using the Microsoft Excel program. Mechanism of liquefaction of sources of income of the village, including the allocation of Funds that were in accordance with the rules of Regent Muaro Jambi Number Number 17 in 2015 about an Ordinance Division and assignment details the village Fund. The stages of preparation of the financial management of the allocation of the funds of the village starts from planning, deployment, and accountability and reporting have been referring to the Regulations the Regents Muaro Jambi 201515 years of Regulatory Guidelines for financial management of the village. To overcome the obstacles faced in the implementation of accounting and financial management of the allocation of funds in the village of Sungai Gelam village development activities against mainly sourced from the village Fund Allocation minimal Socializing, parties should the Government further promotes the village to the community about the latest programs and provide a grace period to understand about the new programs. The role of the community is necessary for the two sides to the good Government of the village as well as the society for mutual cooperation, provide motivation, and knowledge toward the critical role community as trustees so that it can create positive feedback. Coaching through guidance-guidance techniques specifically and routinely socialization can be done to improve the skills of Human Resources in understanding the accounting and record-keeping system for financial management of the allocation of Funds.

Key words: Allocation of the village, the village Fund financial reporting, financial accounting of the village

\section{PENDAHULUAN}

Pembanguan nasional bertujuan untuk mewujudkan masyarakat adil dan makmur yang merata material dan spiritual berdasarkan Pancasila dan UUD RI 1945 dalam wadah Negara Kesatuan Republik Indonesia yang merdeka, bersatu berkedaulatan rakyat. Titik berat pembangunan diletakkan pada bidang ekonomi yang merupakan penggerak utama pembangunan seiring dengan kualitas sumber daya manusia dan didorong secara saling memperkuat, saling terkait dan terpacu dengan pembangunan di bidang-bidang lainnya yang dilaksanakan selaras, serasi, dan seimbang guna keberhasilan pembangunan di bidang ekonomi dalam rangka mencapai tujuan dan sasaran pembangunan nasional. Hal ini merupakan konsekuensi logis bagi bangsa Indonesia yang memang sebagian besar penduduknya hidup di daerah pedesaan. Arti penting pembangunan pedesaan adalah bahwa dengan menempatkan desa sebagai sasaran pembangunan, usaha untuk mengurangi berbagai kesenjangan pendapatan, kesenjangan kaya dan miskin, kesenjangan desa dan kota akan dapat lebih diwujudkan. Hal ini juga menjadi perhatian kabinet Jokowi - JK yang tertuang dalam NAW ACITA khususnya nawacita ke tiga "membangun Indonesia dari pinggir dengan memperkuat daerah dan desa dalam kerangka Negara Kesatuan".

Sejak Undang-undang Nomor 6 tahun 2014 tentang Desa disahkan, desa-desa di Indonesia menjadi bergairah. Sejak tahun 2015, triliunan rupiah digelontorkan sebagai dana desa. Tahun 2015 saja dana desa dialokasikan lebih dari 20 triliun rupiah untuk 74 ribu lebih desa di Indonesia. Alokasi dana desa ini meningkat 
pada tahun 2017 sebesar 60 triliun rupiah yang ditujukan untuk 74.954 desa di 434 kabupaten dan kota. Pada tahun 2019 diperkirakan dana desa akan meningkat mencapai 111 triliun rupiah. Aliran dana yang sangat besar dalam dua tahun terakhir ini tak pelak menimbulkan banyak tantangan dan masalah dalam pengelolaannya. Menurut Peraturan Menteri Dalam Negeri nomor 37 tahun 2007 tentang pedoman pengelolaan keuangan desa, penggunaan anggaran alokasi dana desa adalah sebesar 30\% untuk belanja aparatur dan operasional pemerintah desa, sedangkan sebesar $70 \%$ untuk biaya pemberdayaan masyarakat, yang meliputi biaya perbaikan sarana publik dalam skala kecil, penyertaan modal usaha masyarakat melalui Badan Usaha Milik Desa (BUMDes), biaya untuk pengadaan ketahanan pangan, perbaikan lingkungan dan pemukiman, teknologi tepat guna, perbaikan kesehatan dan pendidikan, pengembangan sosial budaya dan sebagainya yang dianggap penting. (Adisetiawan, 2013)

Laporan pertanggungjawaban itu berpedoman pada Permendagri Nomor 113 tahun 2014 tentang pengelolaan dana desa. Dengan harapan laporan keuangan desa yang telah dihasilkan dapat memberikan informasi yang lengkap, cermat, akurat, tepat waktu sesuai dengan periode yang bersangkutan, akuntabel dan trasparan, dapat mewujudkan tata kelola pemerintahan yang baik (good governance) dan dapat menyebabkan akuntansi cepat diterima dan diakui. Akuntansi merupakan sitem informasi yang mencatat semua kejadian di masa lalu yang menghasilkan informasi berupa laporan keuangan yang dapat berguna bagi pihak internal maupun pihak ekternal untuk dijasikan sebagai dasar pengambilan keputusan. fungsi dari akuntansi adalah untuk menyajikan informasi keuangan kepada pihak internal dan eksternal sebagai dasar membuat keputusan. Tujuan pembukuan keuangan secara umum adalah: (1) untuk mengetahui perkembangan perusahaan dari waktu ke waktu, baik perkembangan omzet penjualan, laba/rugi maupun struktur permodalan, (2) untuk mengetahui kemungkinan kerugian sejak dini, sehingga gulung tikar bisa dihindari, (3) untuk mengetahui kondisi persediaan barang/jasa setiap saat, sehingga dapat digunakan untuk menyusun strategi manajemen persediaan, dan (4) untuk mengetahui sumber dan penggunaan dana desa, sehingga bisa mengevaluasi kinerja keuangan desa secara keseluruhan selama satu periode.

Kesiapan Sumber Daya Manusia (SDM) menjadi tantangan yang besar dalam mengelola dana desa yang transparansi dan akuntabilitas. Salah satu indikator terlaksananya penerapan prinsip akuntansi yang tepat pada adalah melalui penyelenggaraan akuntansi secara tepat dan benar. Penerapan akuntansi dan penyusunan laporan keuangannya harus juga berpedoman pada standar keuangan sehingga laporan keuangan yang disajikan memiliki kepercayaan dari semua pihak. Dengan derasnya arus dana ke pedesaan maka peran akuntan profesional sangat dibutuhkan untuk mendampingi para pengelola dana desa agar akuntabel. Kementrian desa PDT dan transmigrasi ingin memastikan penyaluran dana desa bisa dilakukan dengan transparan dan akuntabel, sehingga pelaporan yang dilakukan oleh aparat desa bisa sesuai standar, dan tidak menyalahi prinsip transparansi dan good governance. (Adisetiawan, 2013)

Artinya dasar pengelolaan harus serba transparan dan terbuka sehingga ada mekanisme chek and balance baik oleh pemerintah desa maupun masyarakat. Sebuah langka besar sedang dirintis oleh pemerintah dengan memberlakukan standar akuntansi disetiap desa. UU No 6 tahun 2014 tentang desa telah mengharuskan setiap desa menyelenggarakan pelaporan keuangan kedepan sesuai standar yang berlaku. Berdasarkan fakta yang ada, masih jarang perangkat desa yang memiliki pemahaman akuntansi yang baik. Maka pantas saja jika selama ini pelaporan keuangan desa sering bermasalah. Selama tahun 2016 saja terdapat 932 laporan pengaduan masyarakat terhadap pelanggaran penyalagunaan dana desa yang masuk di Kemendes PDTT. Dari angka tersebut terdapat lebih dari 200 laporan pengaduan yang sudah diserahkan ke KPK dan 167 laporan diserahkan ke kepolisian, dan banyak pemberitaan di media mengenai penyelewengan dana desa. Rata-rata penyimpangan dana desa karena tidak transparan dan tidak tertib akuntansi. Hal ini harus dimaklumi karena pengelolaan dana desa belum memahami akuntansi atau masih sangat terbatasnya SDM yang memahami akuntansi.

Berangkat dari kasus pro kontra dan kekhawatiran terhadap UU 6/2014 ini, maka peneliti menganggap perlu ada sebuah penelitian lebih lanjut yang dapat memberi solusi terhadap permasalahan yang ada. Hal ini diharapkan dapat mengurangi kekhawatiran banyak pihak, yaitu ada para aparat desa yang berurusan dengan penegak hukum karena ketidaktahuan dan ketidakmampuannya dalam mengelola dana desa. Penelitian ini diharapkan dapat memberikan pemahaman kepada aparat desa tentang akuntansi dan pengelolaan keuangan 
terkait pengelolaan dana desa. Penelitian ini mengharapkan aparat desa mampu melakukan pengelolaan dana desa mulai dari pencatatan sampai pelaporan secara reliabel, dan tepat waktu.

\section{Landasan Teori}

\section{Teori Agensi (Agency Theory)}

Teori agensi merupakan konsep yang menjelaskan hubungan kontraktual antara principals dan agents. Pihak principals adalah pihak yang memberikan mandat kepada pihak lain, yaitu agent, untuk melakukan semua kegiatan atas nama principals dalam kapasitasnya sebagai pengambil keputusan (Jensen dan Smith, 1984). Menurut Anggraini (dalam Arna 2015) di dalam hubungan keagenan, terdapat tiga faktor yang mempengaruhi yaitu biaya pengawasan (monitoring cost), biaya kontrak (contracting cost) dan visibilitas politis. Perusahaan yang menghadapi biaya pengawasan dan kontrak yang tinggi cenderung akan memilih metode akuntansi yang dapat meningkatkan laba yang dilaporkan, dan perusahaan yang menghadapi visibilitas politis yang tinggi cenderung akan memilih metode dan tehnik akuntansi yang dapat melaporkan laba menjadi lebih rendah.

Pada pemerintahan daerah di Indonesia secara sadar atau tidak, teori agensi sebenarnya telah dipraktikkan. Pada organisasi sektor publik yang dimaksud principal adalah rakyat dan agen adalah pemerintah dalam hal ini adalah kepala desa dan aparat desa lainnya. Peraturan Pemerintah Republik Indonesia Nomor 71 Tahun 2010 tentang Standar Akuntansi Pemerintahan memberikan penjelasan tentang adanya hubungan yang jelas antara teori agensi dengan akuntabilitas. Akuntabilitas adalah kewajiban pemegang amanah/agent/kepala desa dan aparatnya untuk memberikan pertanggungjawaban, menyajikan, melaporkan, dan mengungkapkan segala aktivitas dan kegiatan yang menjadi tanggung jawabnya kepada pihak pemberi amanah (principal) yang memiliki hak dan kewenangan untuk meminta pertanggungjawaban tersebut. Secara singkat, kepala desa dan aparaturnya harus mempertanggungjawabkan pengelolaan sumber daya serta pelaksanaan kebijakan yang dipercayakan kepada entitas pelaporan dalam mencapai tujuan yang telah ditetapkan secara periodik.

Transparansi memberikan informasi keuangan yang terbuka dan jujur kepada masyarakat berdasarkan pertimbangan bahwa masyarakat memiliki hak untuk mengetahui secara terbuka dan menyeluruh atas pertanggungjawaban pemerintah dalam pengelolaan sumber daya yang dipercayakan kepadanya dan ketaatannya pada peraturan perundang-undangan. Salah satu cara yang digunakan untuk memonitor masalah kontrak dan membatasi perilaku opportunistic manajemen adalah corporate govenrnance. Corporate governance diarahkan untuk mengurangi asimetri informasi antara principal dan agent yang pada akhirnya dapat diminimalkan tindakan manajemen laba.

\section{Standar Pelaporan Keuangan Pemerintah Desa (Konsep Publikasian)}

Dengan adanya penerimaan yang telah diperoleh oleh Pemerintah Desa salah satunya berupa Alokasi Dana Desa, dengan begitu maka Pemerintah Desa wajib untuk menyusun Laporan Keuangan Desa. Adapun komponen laporan keuangan desa menurut Standar Pelaporan Keuangan Pemerintah Desa (Konsep Publikasian), terdiri atas: Laporan Realisasi Anggaran (LRA) Desa, Neraca Desa, dan Catatan atas Laporan Keuangan (CaLK) Desa. Dimana Laporan Realisasi Anggaran Desa menyediakan informasi mengenai apakah sumber daya ekonomi telah diperoleh dan digunakan sesuai dengan anggaran yang telah ditetapkan. Laporan Realisasi Anggaran Desa memuat anggaran dan realisasi selama periode pelaporan. Laporan Realisasi Anggaran Desa menyajikan ikhtisar sumber, alokasi dan penggunaan sumber daya ekonomi yang dikelola oleh Pemerintah Desa dalam satu periode pelaporan. Basis akuntansi yang digunakan yaitu basis kas. Sedangkan Neraca Desa memberikan informasi mengenai Aset (kekayaan) dan Kewajiban entitas Pemerintah Desa pada tanggal pelaporan dan perubahan kekayaan selama periode berjalan. Informasi ini diperlukan pengguna untuk melakukan penilaian terhadap kemampuan entitas Pemerintah Desa dalam menyelenggarakan kegiatan Pemerintahan Desa di masa mendatang. Neraca desa memuat Aset, Kewajiban, dan Ekuitas pada tanggal pelaporan. Basis akuntansi yang digunakan yaitu basis akrual dan Catatan atas Laporan Keuangan (CaLK) Desa merupakan tugas Pemerintah Desa untuk menyusun Catatan atas Laporan Keuangan Desa agar dapat dipahami dan dibandingkan dengan laporan keuangan entitas lainnya. 


\section{Akuntansi Desa dan Keuangan Desa}

Akuntansi Desa adalah pencatatan dari proses transaksi yang terjadi di desa, dibuktikan dengan notanota kemudian dilakukan pencatatan dan pelaporan keuangan sehingga akan menghasilkan informasi dalam bentuk laporan keuangan yang digunakan pihak-pihak yang berhubungan dengan desa (Sujarweni, 2015:17). Sedangkan menurut Permendagri Nomor 113 Tahun 2014 tentang Pengelolaan Keuangan Desa, dimana keuangan desa adalah semua hak dan kewajiban desa yang dapat dinilai dengan uang serta segala sesuatu berupa uang dan barang yang berhubungan dengan pelaksanaan hak dan kewajiban desa. Pihak-pihak yang menggunakan informasi keuangan desa di antaranya adalah Masyarakat Desa, Perangkat Desa, Pemerintahan Daerah, dan Pemerintahan Pusat.

\section{Anggaran Pendapatan dan Belanja Desa (APBDesa)}

Anggaran Pendapatan dan Belanja Desa menurut (Sujarweni, 2015:33) adalah pertanggungjawaban dari pemegang manajemen desa untuk memberikan informasi tentang segala aktivitas dan kegiatan desa kepada masyarakat dan pemerintah atas pengelolaan dana desa dan pelaksanaan berupa rencana-rencana program yang dibiayai dengan uang desa. Komponen dalam anggaran desa menurut Permendagri Nomor 113 Tahun 2014 tentang Pengelolaan Keuangan Desa terdiri atas akun-akun sebagai berikut: Pendapatan Desa, Belanja Desa, dan Pembiayaan Desa.

Menurut Permendagri Nomor 113 Tahun 2014 tentang Pengelolaan Keuangan Desa, pendapatan desa meliputi semua penerimaan uang melalui rekening desa yang merupakan hak desa dalam 1 tahun anggaran yang tidak perlu dibayar kembali oleh desa. Pendapatan desa terdiri atas kelompok: 1) Pendapatan Asli Desa (PADesa), terdiri atas jenis yaitu hasil usaha, hasil aset, swadaya, partisipasi, dan gotong royong, serta lainlain pendapatan aslidesa; 2) Transfer, terdiri atas jenis yaitu Dana Desa, Bagian dari Hasil Pajak Daerah Kabupaten/Kota dan Retribusi Daerah, Alokasi Dana Desa (ADD), Bantuan Keuangan dari APBD Provinsi, Bantuan Keuangan APBD Kabupaten/Kota; 3) Kelompok pendapatan lainlain, terdiri atas jenis yaitu hibah dan sumbangan dari pihak ketiga yang tidak mengikat, serta Lain lain pendapatan desa yang sah. Menurut Permendagri Nomor 113 Tahun 2014 tentang Pengelolaan Keuangan Desa, belanja desa meliputi semua pengeluaran dari rekening desa yang merupakan kewajiban desa dalam 1 tahun anggaran yang tidak akan diperoleh pembayarannya kembali oleh desa.

Belanja desa terdiri atas kelompok: 1) Penyelenggaraan pemerintahan desa, terdiri atas jenis yaitu Penghasilan tetap dan tunjangan, serta operasional perkantoran; 2) Pelaksanaan pembangunan desa; 3) Pembinaan kemasyarakatan desa; 4) Pemberdayaan masyarakat desa; 5) Belanja tak terduga. Menurut Permendagri Nomor 113 Tahun 2014 tentang Pengelolaan Keuangan Desa, pembiayaan desa meliputi semua penerimaan yang perlu dibayar kembali dan/atau pengeluaran yang akan diterima kembali, baik pada tahun anggaran yang bersangkutan maupun pada tahun-tahun anggaran berikutnya. Pembiayaan desa terdiri atas kelompok: 1) Penerimaan pembiayaan, mencakup Sisa Lebih Perhitungan Anggaran (SiLPA) tahun sebelumnya, Pencairan dana cadangan, dan Hasil penjualan kekayaan desa yang dipisahkan; 2) Pengeluaran pembiayaan, mencakup Pembentukan dana cadangan, dan Penyertaan modal desa.

\section{Alokasi Dana Desa}

Menurut Undang-Undang Nomor 6 Tahun 2014 tentang Desa, Alokasi Dana Desa merupakan bagian dari dana perimbangan yang diterima Pemerintah Daerah Kabupaten/Kota paling sedikit 10\% (sepuluh per seratus) setelah dikurangi Dana Alokasi Khusus. Pengalokasian Alokasi Dana Desa terlebih dahulu harus mempertimbangkan kebutuhan penghasilan tetap Kepala Desa dan Perangkat Desa, jumlah penduduk desa, angka kemiskinan desa, luas wilayah desa, dan tingkat kesulitan geografis desa (Peraturan Pemerintah Nomor 47 Tahun 2015 Pasal 96 tentang Perubahan Atas Peraturan Pemerintah Nomor 43 Tahun 2014 tentang Peraturan Pelaksanaan Undang-Undang Nomor 6 Tahun 2014 tentang Desa).

Penyaluran Alokasi Dana Desa dilakukan dengan cara pemindah bukuan dari Kas Umum Daerah ke Rekening Kas Desa yang dilaksanakan secara bertahap pada tahun anggaran berjalan. Dimana penyaluran tersebut terdiri dari 4 tahap yaitu: tahap pertama sebesar $20 \%$ (dua puluh per seratus), tahap kedua sebesar $20 \%$ (dua puluh per seratus), tahap ketiga sebesar 30\% (tiga puluh per seratus), dan tahap keempat yaitu berdasarkan selisih antara pagu alokasi dengan dana yang telah di transfer pada tahap pertama, kedua, serta 
ketiga (Perbup Nomor 15 Tahun 2015 tentang Tata Cara Penyaluran Alokasi Dana Desa, Bagi Hasil Pajak Daerah, dan Retribusi Daerah, dan Dana Desa). Menurut Peraturan Menteri Dalam Negeri Nomor 37 Tahun 2007 tentang Pedoman.

Pengelolaan Keuangan Desa, penggunaan anggaran Alokasi Dana Desa adalah sebesar 30\% (tiga puluh persen) untuk belanja aparatur dan operasional pemerintah desa, sedangkan sebesar $70 \%$ (tujuh puluh persen) untuk biaya pemberdayaan masyarakat, yang meliputi biaya perbaikan sarana publik dalam skala kecil, penyertaan modal usaha masyarakat melalui BUMDesa, biaya untuk pengadaan ketahanan pangan, perbaikan lingkungan dan pemukiman, teknologi tepat guna, perbaikan kesehatan dan pendidikan, pengembangan sosial budaya, dan sebagainya yang dianggap penting.

Rumus yang dipergunakan dalam Alokasi Dana Desa berdasarkan Peraturan Menteri Dalam Negeri Nomor 37 Tahun 2007 tentang Pedoman Pengelolaan Keuangan Desa, adalah: 1) Azas Merata, adalah besarnya bagian Alokasi Dana Desa yang sama untuk setiap desa yang selanjutnya disebut Alokasi Dana Desa Minimal (ADDM), dan 2) Azas Adil, adalah besarnya bagian Alokasi Dana Desa berdasarkan Nilai Bobot Desa (BDx) yang dihitung dengan rumus dan variabel tertentu, (misalnya kemiskinan, keterjangkauan, pendidikan dasar, kesehatan dll) selanjutnya disebut Alokasi Dana Desa Proporsional (ADDP). Besarnya prosentase perbandingan antara azas merata dan adil adalah besarnya ADDM adalah $60 \%$ (enam puluh persen) dari jumlah ADD dan besarnya ADDP adalah 40\% (empat puluh persen) dari jumlah ADD.

\section{Laporan Pertanggung Jawaban Alokasi Dana Desa}

Pertanggung jawaban Alokasi Dana Desa (ADD) terintegrasi dengan pertanggung jawaban APBDesa, sehingga bentuk pertanggungjawabannya adalah pertanggungjawaban APBDesa. Menurut Peraturan Menteri Dalam Negeri Nomor 37 Tahun 2007 tentang Pedoman Pengelolaan Keuangan Desa, bentuk pelaporan atas kegiatankegiatan dalam APBDesa yang dibiayai dari Alokasi Dana Desa adalah laporan berkala dan laporan akhir. Dimana laporan berkala merupakan laporan mengenai pelaksanaan penggunaan dana Alokasi Dana Desa dibuat secara rutin setiap bulannya. Adapun yang dimuat dalam laporan ini adalah realisasi penerimaan Alokasi Dana Desa dan realisasi belanja Alokasi Dana Desa. Sedangkan laporan akhir merupakan laporan atas penggunaan Alokasi Dana Desa yang mencakup perkembangan pelaksanaan dan penyerapan dana, masalah yang dihadapi dan rekomendasi penyelesaian hasil akhir penggunaan Alokasi Dana Desa.

\section{METODE}

Jenis data yang digunakan dalam penelitian ini adalah data primer dan data sekunder. Sumber data diperoleh dari pengurus, sekretaris dan bendahara desa Sungai Gelam Kecamatan Sungai Gelam Kabupaten Muaro Jambi berupa data hasil laporan dan pembukuan keuangan dana desa dan berupa dokumen penting lainnya. Tehnik pengumpulan data dilakukan secara triangulasi (gabungan), berupa pengamatan (observation), wawancara (interview), kepustakaan (library reaserch), dan dokumentasi (documentation). Metode analisis yang digunakan penulis dalam penelitian ini adalah deskriptif dengan menggunakan pendekatan kualitatif dengan Operasional variabel sebagai berikut: a) Akuntansi Desa, Akuntansi desa adalah pencatatan dari proses transaksi yang terjadi di desa, dibuktikan dengan nota-nota kemudian dilakukan pencatatan dan pelaporan keuangan sehingga akan menghasilkan informasi dalam bentuk laporan keuangan yang digunakan pihak-pihak yang berhubungan dengan desa (Sujarweni, 2015:17); b) Pengelolaan Keuangan Desa, menurut Permendagri nomor 113 tahun 2014 tentang pengelolaan keuangan desa yang berarti keseluruhan kegiatan yang meliputi perencanaan, pelaksanaan, penatausahaan, pelaporan dan pertanggungjawaban keuangan desa, dan c) Alokasi Dana Desa (ADD) Menurut undang-undang Nomor 6 tahun 2014 tentang Desa, dimana Alokasi dana Desa (ADD) merupakan bagian dari dana perimbangan yang diterima Kabupaten/kota paling sedikit 10\%, dalam anggaran pendapatan belanja daerah setelah dikurangi dana alokasi khusus.

\section{HASIL}

Berdasarkan wilayah administrasi Desa Sungai Gelam merupakan sebuah desa yang berada di sebuah kecamatan di kabupaten Muaro Jambi yang merupakan pemekaran dari kecamatan Jambi Luar Kota dan Kumpeh Ulu, dengan batas-batas wilayah administrasi Sebelah Utara dengan kecamatan Mestong, Sebelah 
Timur dengan kecamatan Kumpeh ulu, Sebelah Selatan dengan Kota jambi dan Sebelah Barat dengan kecamatan Jambi Luar Kota. Wilayah Desa Sungai Gelam mempunyai 9 (Sembilan) Rukun Tetangga (RT) dengan penduduk mayang yoritas pekerjaannya sebagai petani sawit dan petani karet, namun ada juga masyarakat yang berprofesi sebagai buruh pabrik, pegawai, guru dan sebagainya. dilihat dari segi sumber daya manusia sangat mungkin untuk menjadi desa yang produkstif dan mandiri sehingga dapat menjadi desa yang berkatagori maju.

Untuk melaksanakan roda Pemerintahan Desa, maka landasan hukum yang dijadikan sebagai pedoman oleh Pemerintah Desa khususnya di Desa sungai gelam Kecamatan sungai gelam Kabupaten sungai gelam pada tahun 2015, yaitu: 1) Undang-Undang Nomor 17 Tahun 2003 tentang Keuangan Negara; 2) UndangUndang Republik Indonesia Nomor 32 Tahun 2004 tentang Pemerintahan Daerah; 3) Undang-Undang Republik Indonesia Nomor 33 Tahun 2004 tentang Perimbangan Keuangan Antara Pemerintah Pusat dan Pemerintahan Daerah; 4) Undang-Undang Republik Indonesia Nomor 6 Tahun 2014 tentang Desa; 5) Peraturan Pemerintah Republik Indonesia Nomor 47 Tahun 2015 tentang Perubahan Atas Peraturan Pemerintah Nomor 43 tahun 2014 tentang Peraturan Pelaksanaan Undang-Undang Nomor 6 Tahun 2014 tentang Desa; 6) Peraturan Menteri Dalam Negeri Nomor 37 Tahun 2007 tentang Pedoman Pengelolaan Keuangan Desa; 7) Peraturan Menteri Dalam Negeri Nomor 35 Tahun 2007 tentang Pedoman Umum Tata Cara Pelaporan dan Pertanggungjawaban Penyelenggaraan Pemerintahan Desa; 8) Peraturan Bupati muaro jambi nomor 15 tahun 2015 tentang Pedoman Pengelolaan Keuangan Desa; 9) Peraturan Bupati Muaro jambi Nomor 16 Tahun 2015 tentang penetapan Alokasi dana desa ; 10) Peraturan Bupati muaro jambi Nomor 17 tahun 2015 tentang tata cara pembagian dan penetapan rincian dana desa, dan 10) Peraturan Desa sungai gelam Nomor 17 Tahun 2016 tentang Anggaran Pendapatan dan Belanja Desa sungai gelam Tahun 2016.

Adapun tahapan penyusunan APBDesa di desa Sungai Gelam meliputi: 1) Pemerintah Desa mengajukan rancangan peraturan desa kepada BPD (Badan Permusyawaratan Desa), setelah itu BPD (Badan Permusyawaratan Desa) membahas rancangan peraturan desa tersebut untuk dibahas bersama dalam rangka memperoleh persetujuan atau tidak; 2) Setelah memperoleh persetujuan dari BPD (Badan Permusyawaratan Desa), maka BPD (Badan Permusyawaratan Desa) membuat Surat Keputusan BPD (Badan Permusyawaratan Desa); dan 3) Kemudian Pemerintah Desa dengan dasar Surat Keputusan BPD (Badan Permusyawaratan Desa) tersebut, Pemerintah Desa membuat keputusan tentang Anggaran dan Pendapatan Belanja Desa (APBDes).

\section{Penerapan Akuntansi dan Pengelolaan Keuangan Alokasi Dana Desa di Desa Sungai Gelam Kecamatan Sungai Gelam Kabupaten Muaro Jambi}

Penerapan pencatatan akuntansi keuangan alokasi dana desa telah sesuai dengan peraturan Bupati Muaro Jambi no 64 tahun 2014 tentang sistem akuntansi pemerintah kabupaten Muaro Jambi. Sistem pencatatan akuntansi keuangan alokasi dana desa dibantu oleh komputer yaitu dengan menggunakan program Microsoft Excel yang berupa buku kas umum dan buku kas pembantu penerimaan serta buku kas pembantu pengeluaran. Buku kas umum adalah buku kas yang digunakan untuk mencatat berbagai aktivitas yang menyangkut penerimaan dan pengeluaran kas baik secara tunai maupun kredit. Buku kas pembantu penerimaan serta buku kas pembantu pengeluaran adalah buku kas yang digunakan untuk mencatat setiap pemasukan sumber dana yang diterima, dan mencatat setiap transaksi-transaksi pengeluaran yang akan dijabarkan ke dalam buku kas pengeluaran sesuai dengan APBDesa. Di tahun 2017 perkembangan sistem akuntansi keuangan desa khususnya untuk semua pencatatan terhadap sumber pendapatan desa yang di peroleh oleh desa Sungai Gelam Kecamatan Sungai Gelam Kabupaten Muaro Jambi terutama yang bersumber dari alokasi dana desa menggunakan sistem pencatatan yang terkomputerisasi secara online, baik untuk pencatatan akuntansi desa hingga pelaporan transaksi keuangan desa. Ditandai dengan penerapan secara bertahap dengan menggunakan aplikasi Sistem Keuangan Desa (Siskeudes) dan Sistem Informasi Desa (SID). Dengan adanya aplikasi Sistem Keuangan Desa (Siskeudes) dan Sistem Informasi Desa (SID) dapat memudahkan pihak pemerintah desa di dalam mengelola tata kelola keuangan desa terutama dari segi pelaporan dan pertanggungjawabannya kepada pemerintah pusat dan pemerintah daerah maupun masyarakat atas dana yang telah di gunakan, serta agar lebih efisien, efektif dan ekonomis. Sedangkan penerapan pengelolaan keuangan alokasi dana desa pada tahun 2017 di desa Sungai Gelam Kecamatan Sungai Gelam 
Kabupaten Muaro Jambi, cukup baik dan realistis karena sudah tersusun di dalam Rencana Anggaran Biaya (RAB), walaupun terkadang pencairan dananya mengalami sedikit kendala. Untuk pengelolaan dana yang bersumber dari alokasi dana desa tersebut harus difokuskan pada sarana dan prasarana desa. Sedangkan pembagiannya sendiri dari pelaksanaan APBDes itu 30\% untuk penyelenggaraan Pemerintahan desa dan 70\% untuk kegiatan yang lainnya.

\section{Mekanisme Pencairan Alokasi Dana Desa di Desa Sungai Gelam Kecamatan Sungai Gelam Kabupaten Muaro Jambi}

Mekanisme pencairan sumber pendapatan desa yang di dalamnya termasuk alokasi dana desa yang telah sesuai dengan Peraturan Bupati Muaro Jambi Nomor 17 tahun 2015 tentang tata cara pembagian dan penetapan rincian dana desa. Dimana pihak pemerintah desa pada saat menerima sumber pendapatan desa yang di dalamnya termasuk alokasi dana desa tersebut terlebih dahulu menunggu berita dari kabupaten Muaro Jambi, apakah dana tersebut sudah cair apa belum yang akan di transfer dari rekening kas umum daerah (RKUD) ke rekening kas desa (RKD). Namun hanya saja pihak pemerintah desa tidak mengetahui secara pasti prosentase dana yang diterimanya, dikarenakan pemerintah desa pada saat menerima sejumlah dana dari pemerintah daerah tersebut langsung jadi yang tertera di rekening koran tanpa mengetahui prosentasenya.

\section{Tahapan Penyusunan Pengelolaan Keuangan Alokasi Dana Desa di Desa Sungai Gelam Kecamatan Sungai Gelam Kabupaten Muaro Jambi}

\section{A. Perencanaan}

Di dalam pengelolaan keuangan desanya yang ada di desa Sungai Gelam Kecamatan Sungai Gelam Kabupaten Muaro Jambi terutama pengelolaan keuangan alokasi dana desa telah berpedoman pada peraturan Bupati Muaro Jambi Nomor 15 Tahun 2015 tentang pedoman pengelolaan keuangan desa. Diawali dengan musyawarah desa yang dihadiri oleh Penanggung Jawab (PJ) kepala desa Sungai Gelam beserta perangkat desa, dan Ketua Badan Permusyawaratan Desa (BPD) beserta anggotanya. Untuk membahas usulan-usulan atas program pembangunan desa yang diperoleh dari masing-masing lingkungan tiap RT sehingga dapat dijadikan acuan untuk penyusunan Rencana Anggaran Biaya (RAB) dan persetujuan oleh Badan Permusyawaratan Desa (BPD) mengenai Rancangan Peraturan Desa tentang APBD desa tahun 2015. Dimana Sekretaris Desa menyusun Rancangan Peraturan Desa tentang APBDesa berdasarkan RKPDesa dan menyusun Rencana Anggaran Biaya (RAB) sebagai dasar pelaksanaan anggaran desa sesuai dengan usulan usulan atas program pembangunan desa yang diperoleh dari masing-masing lingkungan tiap RT berdasarkan skala prioritas yang diutamakan. Setelah itu Sekretaris Desa menyampaikan rancangan Peraturan Desa tentang APBDesa dan Rencana Anggaran Biaya (RAB) kepada Kepala Desa, lalu Kepala Desa menyampaikan rancangan Peraturan Desa tentang APBDesa dan Rencana Anggaran Biaya (RAB) tersebut kepada Badan Permusyawaratan Desa (BPD) untuk dibahas kembali dan memperoleh pengesahan bersama. Sehingga kemudian Rancangan Peraturan Desa tentang APBDesa yang telah disepakati bersama disampaikan oleh Kepala Desa kepada Camat dengan dilampiri Rencana Anggaran Biaya (RAB) untuk dievaluasi.

\section{B. Penggunaan}

Penggunaan dana terutama dana yang bersumber dari alokasi dana desa telah mengacu pada rencana pembangunan jangka menengah desa (RPJMDes) dan rencana kerja pemerintah desa (RKPDes), walaupun terkadang pada saat implementasi yang ada di lapangan atas penggunaan dana terutama dana yang bersumber dari alokasi dana desa tersebut jarang sekali rencana pembangunan jangka menengah desa (RPJMDes) untuk dijadikan sebagai patokan dikarenakan setiap tahun kondisi di lapangan itu berbeda, sehingga rencana pembangunan jangka menengah desa (RPJMDes) disesuaikan kembali dengan kondisi yang sedang terjadi di lapangan. Alokasi dana desa yang diterima digunakan untuk penghasilan tetap dan tunjangan perangkat desa, operasional perkantoran meliputi belanja pakai habis, jasa kantor, perawatan kendaraan bermotor, cetak dan penggandaan, makanan dan minuman rapat, dan honorarium pengelola keuangan, tunjangan BPD, pengembangan sistem administrasi dan informasi desa, serta penyusunan produk hukum desa.

\section{Pertanggungjawaban dan Pelaporan}

Pertanggungjawaban dan pelaporan dana terutama dana yang bersumber dari alokasi dana desa telah sesuai dengan Peraturan Bupati Muaro Jambi Nomor 15 Tahun 2015 tentang pedoman pengelolaan keuangan 
desa yang telah terintegrasi pada laporan pertanggung jawaban(LPJ) APBDesa yang berisi buku kas umum (BKU), kuitansi, nota, tanda terima kegiatan,dan lampiran-lampiran kegiatan lainnya serta pelaporannya atas realisasi penggunaan alokasi dana desa melalui 2 tahap, yaitu semester 1 di laporkan pada bulan Juni 2017 sedangkan semester 2 di laporkan pada bulan Desember 2017, serta pelaporannya masih dalam bentuk seperti buku yang dijilid yang akan di laporkan ke Kecamatan kemudian ke Kabupaten.

\section{Kendala Yang Dihadapi Di Dalam Penerapan Akuntansi dan Pengelolaan Keuangan Alokasi Dana Desa di Desa Sungai Gelam Kecamatan Sungai Gelam kabupaten Muaro Jambi}

1. Kapasitas Sumber Daya Manusia

Di desa Sungai Gelam terdapat beberapa kendala yang terletak pada perangkat desa. Dimana perangkat desanya tersebut masih ada beberapa yang belum kompeten dikarenakan tingkat pendidikannya rendah dan faktor usia. Dari segi pendidikan dan faktor usia menjadi faktor penyebab utama yang melatar belakangi kendala di dalam jalannya sistem pemerintahan yang ada di desa Sungai Gelam terutama mengenai pencatatan Akuntansi dan Pengelolaan Keuangan Alokasi Dana Desa. Di karenakan hal tersebut membuat para perangkat desa tidak kompeten di bidang akuntansi desa dan pengelolaan keuangan alokasi dana desa sehingga dapat menyebabkan kesulitan bagi para perangkat desa khususnya kepala seksi keuangan untuk menyusun laporan keuangan dan mengikuti perkembangan terbaru mengenai dasar hukum yang digunakan mengingat peraturan yang dibuat oleh Pemerintah selalu berubah-ubah.

2. Ketanggapan Sosial Terhadap Kegiatan Pembangunan Desa Terutama Yang Bersumber Dari ADD Minim Sosialisasi.

Ketanggapan sosial ini terjadi dikarenakan minimnya sosialisasi yang dilakukan oleh perangkat desa kepada masyarakat terhadap rencana-rencana program tahunan pemerintahan desa yang telah dituangkan ke dalam anggaran pendapatan dan belanja desa (APBDesa). Salah satu contoh seperti tugas seorang kepala dusun (RT) yaitu wajib memberikan informasi yang up to date terkait dengan kondisi di lingkungan sekitar ke kepala desa misalnya memberikan informasi terkait ada orang yang meninggal dunia, ada orang yang kecelakaan, ada orang yang kesusahan, program pembangunan desa, dan lain sebagainya namun namanya manusia kadang-kadang memberikan informasi terkadang tidak memberikan informasi sehingga tahu-tahu kepala desa langsung mendapat teguran dari lingkungan.

3. Peran Serta Masyarakat

Masyarakat memiliki peranan sebagai pengawas atas segala kegiatan yang ada di Pemerintahan Desa, dikarenakan sumber dana yang telah digunakan oleh Pemerintah Desa tersebut salah satunya ada yang bersumber dari masyarakat. Namun terkadang masyarakatnya sendiri yang tidak peka terhadap kemajuan pembangunan di lingkungan sekitarnya. Sehingga dapat menyebabkan rendahnya peran pengawasan oleh masyarakat akan implementasi kegiatan pembangunan desa yang bersumber dari Alokasi Dana Desa. Namun terdapat juga faktor-faktor utama yang mendorong dalam keberhasilan penerapan pencatatan Akuntansi dan Pengelolaan Keuangan Alokasi Dana Desa di Desa Sungai Gelam Kecamatan Sungai Gelam Kabupaten Muaro Jambi berupa Perangkat Desa yang ada di dalamnya menjalin relasi yang cukup baik antar desa yang satu dengan desa yang lain. Relasi tersebut bertujuan untuk saling bekerjasama, menjalin kekompakan, dan mengkonsultasikan setiap kendala yang sedang terjadi.

\section{Upaya Yang Dilakukan Dalam Mengatasi Kendala Yang Terjadi Di Dalam Penerapan Akuntansi Dan Pengelolaan Keuangan Alokasi Dana Desa Di Desa Sungai Gelam Kecamatan Sungai Gelam Kabupaten Muaro Jambi}

Untuk menanggulangi rendahnya kapasitas sumber daya manusia terutama pada perangkat desa, maka terkait dengan rendahnya tingkat pendidikan dan faktor usia menjadi hal penting yang harus di pertimbangkan oleh kepala desa pada periode yang akan datang untuk lebih selektif lagi di dalam menentukan para calon perangkat desa yang sesuai dengan pedoman yang sudah diatur di dalam Undang-Undang Nomor 6 Tahun 2014 tentang desa. Selain itu dilakukan pembinaan melalui bimbingan-bimbingan teknis secara khusus, meminta panduan untuk konsultasi ke Kecamatan Sungai Gelam, dan sosialisasi secara rutin dengan durasi waktu yang lama tentang peraturan terbaru yang telah di buat oleh pemerintah. Diharapkan dengan adanya bimbingan teknis secara khusus, konsultasi ke Kecamatan Sungai Gelam dengan pihak-pihak yang lebih 
memahami masalah yang sedang terjadi, dan sosialisasi secara rutin tersebut dapat membantu perangkat desa khususnya kepala seksi keuangan untuk dapat memahami sistem pencatatan akuntansi dan pengelolaan keuangan alokasi dana desa sehingga dapat menyusun laporan keuangan sesuai dengan prosedur yang telah diatur di dalam peraturan perundang-undangan, dapat meningkatkan keterampilan pencatatan akuntansi yang dapat menghasilkan laporan keuangan desa secara lengkap, akurat, dan tepat waktu, serta dapat dengan cepat beradaptasi dengan peraturan terbaru.

Upaya lain yang dapat dilakukan untuk mengatasi kendala lain yang dihadapi di desa Sungai Gelam yaitu menambah jumlah perangkat desa sesuai dengan kapasitas yang dibutuhkan. Dikarenakan masih ada beberapa bagian pada perangkat desa yang masing kosong yaitu kepala seksi keuangan, kepala seksi kesejahteraan rakyat, dan kepala seksi ketentraman dan ketertiban. Sehingga dengan bertambahnya jumlah perangkat desa yang sesuai dengan kapasitas yang ada dapat meminimalkan adanya perangkapan jabatan dan dapat menyebabkan pembagian tugas yang sesuai dengan jobdisk masing-masing. Memberikan pengarahan kepada para perangkat desa untuk lebih mensosialisasikan kepada masyarakat tentang program-program terbaru yang telah di buat di dalam anggaran pendapatan dan belanja desa (APBDesa) dan memberikan tenggang waktu kepada masyarakat sehingga pemahaman tentang program-program terbaru tersebut bisa diterima dengan baik yang dapat berdampak pada kemajuan pembangunan desa.

Mengingat masih minimnya sosialisasi yang ditujukan kepada masyarakat sehingga dapat berdampak pada rendahnya peran serta masyarakat. Hal ini menyebabkan terkadang masyarakatnya kurang peka dan dapat menyebabkan rendahnya peran pengawasan yang dilakukan oleh masyarakat. Untuk mengatasi kondisi yang seperti ini dibutuhkan kesadaran yang sangat tinggi bagi ke dua belah pihak baik dari Pemerintah Desa maupun masyarakatnya untuk saling bekerjasama, memberikan motivasi, dan pengetahuan terhadap peranan penting masyarakat sebagai pengawas sehingga dapat menciptakan feedback positif yang dapat menunjang keberhasilan akan implementasi kegiatan pembangunan desa yang bersumber dari alokasi dana desa.

\section{SIMPULAN}

Simpulan pada penelitian ini adalah sebagai berikut:

a. Setiap kegiatan pencatatan atas transaksi yang berasal dari alokasi dana desa di desa Sungai Gelam Kecamatan Sungai Gelam Kabupaten Muaro Jambi telah menggunakan sistem pencatatan akuntansi keuangan alokasi dana desa dibantu oleh komputer yaitu dengan menggunakan program Microsoft Excel yang berupa buku kas umum dan buku kas pembantu penerimaan serta buku kas pembantu pengeluaran. Dengan adanya penerapan secara bertahap mengenai aplikasi Sistem Keuangan Desa (Siskeudes) dan Sistem Informasi Desa (SID) seperti profil desa, maka sistem pencatatan akuntansi yang ada nantinya akan dilakukan dengan sistem pencatatan yang terkomputerisasi secara online. Sedangkan untuk pengelolaan keuangan alokasi dana desa pada tahun 2017 cukup baik dan realistis. Dimana salah satu dari sumber pendapatan desa tersebut di peroleh berupa alokasi dana desa yang difokuskan untuk sarana dan prasarana desa;

b. Mekanisme pencairan sumber pendapatan desa yang di dalamnya termasuk alokasi dana desa yang ada di desa Sungai Gelam Kecamatan Sungai Gelam Kabupaten Muaro Jambi telah sesuai dengan Peraturan Bupati Muaro Jambi Nomor Nomor 17 tahun 2015 tentang tata cara pembagian dan penetapan rincian dana desa. Dimana semua penerimaan yang di peroleh oleh desa Sungai Gelam atas pencairan sumber pendapatan desa terutama yang berupa alokasi dana desa yang di transfer oleh kabupaten Muaro Jambi melalui kas daerah, terpusat menjadi satu di rekening koran.

c. Tahapan penyusunan pengelolaan keuangan alokasi dana desa yang ada di desa Sungai Gelam Kecamatan Sungai Gelam Kabupaten Muaro Jambi telah mengacu pada Peraturan Bupati Muaro Jambi Peraturan 15 tahun 2015 tentang Pedoman Pengelolaan Keuangan Desa, dimulai dari perencanaan, penggunaan, serta pertanggungjawaban dan pelaporan; dan

d. Ada beberapa kendala yang dihadapi di dalam penerapan akuntansi dan pengelolaan keuangan alokasi dana desa di desa Sungai Gelam, mencakup kapasitas sumber daya manusia, ketanggapan sosial terhadap kegiatan pembangunan desa terutama yang bersumber dari ADD Minim Sosialisasi, dan peran serta masyarakat. 


\section{DAFTAR PUSTAKA}

Adisetiawan, R., 2013, Kajian Persepsi Penilik Usaha Kecil dan Menengah (UKM) Terhadap Laporan Keuangan, Jurnal Ilmiah Universitas Batanghari, 13(4), 162-173

Arna Suryani, Eva Harianti. 2015. Pengaruh Pengungkapan Tanggung Jawab Sosial Perusahaan Terhadap Koefisen Respon Laba dan Manajemen Laba. Simposium Nasional Akuntansi (SNA) XVIII, Medan.

Jensen, M dan Smith Jr., 1984. The modern theory of corporate finance. New York: McGraw-Hill

Komite Standar Akuntansi pemerintah (KSAP). 2016. Konsep Publikasian Standar Pelaporan Keuangan pemerintah Desa. Jakarta

Mardiasmo. 2005. Akuntansi Sektor Public. Penerbit Andi. Yogyakarta.

Peraturan Menteri Dalam Negeri Republik Indonesia nomor 35 Tahun 2007. Pedoman Umum Tata Cara Pelaporan dan Pertanggungjawaban Penyelenggaraan Pemerintahan Desa. 24 juli 2007. Jakarta

. Nomor 37 tahun 2007. Pedoman Pengelolaan Keuangan Desa Menteri Dalam Negeri. 24 juli 2007. Jakarta

. Nomor 113 tahun 2014. Pengelolaan Keuagan Desa. 31 Desember 2014. Berita Negara Republik Indonesia, Tahun 2014 nomor 2093. Jakarta

Peraturan Pemerintas Republik Indonesia Nomor 43 tahun 2014. Peraturan Pelaksanaan Undang-Undang Nomor 6 tahun 2014 Tentang Desa. 30 Mei 2014. Lembaran Negara Republik Indonesia Tahun 2014 nomor 123. Jakarta

Sugiono. 2015. Metode Penelitian Kuantitatif Kualitatif dan R\&D. Afabeta. Bandung

Sujarweni, V, W. 2015. Akuntansi Desa Pedoman Tata Kelola Keuangan Desa. Pustaka Baru Press. Yogyakarta

Undang-Undang Republik Indonesia Nomor 1 tahun 2004. Perbendaharaan Negara. 14 Januari 2004. Lembaran Negara Republik Indonesia Tahun 2004 nomor 5. Jakarta

. Nomor 6 tahun 2014. Desa. 15 Januari 2014. Lembaran Negara Republik Indonesia Tahun 2014 nomor 7. Jakarta

. Nomor 17 tahun 2003. Keuangan Negara. 15 Januari 2014. Lembar Negara Republik Indonesia Tahun 2003 nomor 47. Jakarta

. Nomor 32 tahun 2004. Pemerintahan Daerah. 1 Oktober 2004. Lembaran Negara Republik Indonesia

Tahun 2004 nomor 125. Jakarta

. Nomor 33 tahun 2004. Perimbangan Antara Keuangan Pemerintah Pusat dan Pemerintah Daerah. 15 Oktober 2004. Lembaran Negara RepubliK Indonesia Tahun 2004 nomor 126. Jakarta

Widjaja, HAW. 2003. Otonomi desa merupakan otonomi yang asli, bulat dan utuh. Raja Grafindo persada. Jakarta. 